\title{
Allelic polymorphism of apple varieties of national selection by genes for scab resistance
}

\author{
Alexander Lyzhin*, and Natalya Savelyeva \\ Federal State Budgetary Scientific Institution "Federal Scientific Center named after I. V. Michurina", \\ 393770, Russia, Michurinsk, st. Michurina, 30
}

\begin{abstract}
Annotation. The results of the analysis of allelic polymorphism of apple varieties of national selection for $\mathrm{R}$ genes of scab resistance are shown. The Rvi6 gene was not identified in the studied forms (putative rvi6rvi6 genotype). The Rvi4 gene was identified in the varieties Grushovka Moskovskaya and Titovka. Genes Rvi2 (Rvi8) - in varieties Pouring yellow, Antonovka kamenichka, Antonovka ordinary, Scarlet anis, Arkad red, Cinnamon striped, Grushovka Moskovskaya, Titovka, Mironchik, Suislepskoe.
\end{abstract}

Scab (Venturia inaequalis (Cooke) G. Winter) is the most harmful and economically significant disease of the apple tree in the world. During the years of epiphytotic development, scab is capable of destroying up to $70 \%$ of marketable fruits $[1,2]$. Most of the commercially important apple varieties are moderately or highly susceptible to $V$. inaequalis $[3,4]$. The primary method to control the spread of $V$. inaequalis in industrial plantings is the widespread use of fungicides, which, however, has a negative impact on the environment, and leads to significant financial costs [5]. In this regard, the use of varieties and forms of plants with the genetically determined resistance to diseases becomes a necessary condition for economically feasible cultivation of agricultural crops, and selection is an important factor in increasing yields $[6,7]$.

The local and ancient varieties are a valuable source material for apple breeding. Many national varieties have high commercial and consumer qualities of fruits, resistance to a complex of abiotic environmental factors, polygenic resistance to fungal pathogens, including $V$. inaequalis [8]. However, for a number of significant breeding traits, varieties of national breeding have not been studied enough, in particular, for many forms there is no data on the presence or absence of monogenic scab resistance loci in the genome, which could presumably be introgressed from the original wild apple species.

This study presents the results of the analysis of the allelic state of local and ancient apple varieties by genes for the scab resistance.

The studies were carried out in the period of 2018-2020. As biological objects used apple varieties of national selection of the genetic collection of the Federal State Budgetary Scientific Institution "FSI named after I.V. Michurin". Varieties Prima (Rvi6 gene), Kandil Orlovsky (Rvi4 gene), Witos (Rvi2 and Rvi8 genes) were used as control.

Extraction of total apple DNA was carried out using a modified STAB method [9].

*Corresponding author: Ranenburzhetc@yandex.ru 
The alleles of the Rvi6 gene were identified using the AL07-SCAR marker (for 5'TGGAAGAGAGATCCAGAAAGTG-3 'rev 5'-CATCCCTCCACAAATGCC-3') [10], the Rvi4 gene was the dominant SCAR marker AD13 (for 5'-GTAAGTCCTCTAG 3 ' 5'GGTTCCTCTGCCCAACAA-3 ') [10], genes Rvi2 and Rvi8 - the dominant SCAR marker OPL19 (for 5'-ACCTGCACTACAATCTTCACTAATC-3' rev 5'GACTCGTTTCCACTGAGGATATTTG-3 ') [11

The reaction mixture in a total volume of $15 \mu$ l contained: $1.5 \mathrm{mM}$ Taq buffer, $2.0 \mathrm{mM}$ deoxynucleoside triphosphate mixture, $2.5 \mathrm{mM}$ magnesium chloride, $0.2 \mu \mathrm{M}$ each primer, $0.2 \mathrm{U}$ Taq polymerase, and $20 \mathrm{ng}$ total DNA.

The polymerase chain reaction was carried out in a T100 amplifier (BIO-RAD) in the following modes:

- SCAR marker AL07: initial denaturation $10 \mathrm{~min}$ at $95^{\circ} \mathrm{C}$, then 35 cycles: $30 \mathrm{sec}$ at 95 ${ }^{\circ} \mathrm{C}, 1 \mathrm{~min}$ at $59^{\circ} \mathrm{C}, 2 \mathrm{~min}$ at $72^{\circ} \mathrm{C}$; then final elongation for $10 \mathrm{~min}$ at $72{ }^{\circ} \mathrm{C}$;

- SCAR marker AD13: initial denaturation 2 min at $94^{\circ} \mathrm{C}$, then 30 cycles: 1 min at $94^{\circ}$ $\mathrm{C}, 3 \mathrm{~min}$ at $58^{\circ} \mathrm{C}, 2 \mathrm{~min}$ at $72^{\circ} \mathrm{C}$; then $1 \mathrm{~min}$ at $94^{\circ} \mathrm{C}, 3 \mathrm{~min}$ at $58^{\circ} \mathrm{C}$ and final elongation for $10 \mathrm{~min}$ at $72^{\circ} \mathrm{C}$;

- SCAR marker OPL19: initial denaturation $2 \mathrm{~min} 45 \mathrm{sec}$ at $94^{\circ} \mathrm{C}$, then 40 cycles: 55 sec at $94^{\circ} \mathrm{C}, 55 \mathrm{sec}$ at $55^{\circ} \mathrm{C}, 1 \mathrm{~min} 39 \mathrm{sec}$ at $72^{\circ} \mathrm{C}$; then final elongation for $10 \mathrm{~min}$ at 72 ${ }^{\circ} \mathrm{C}$.

The amplification products were separated by the electrophoretic method in agarose gel (agarose concentration - 2\%, buffer system - 1x TBE). The amplicon size determination was performed using a Gene Ruler 100 p.n DNA Ladder (Thermo Fisher Scientific).

According to the studies, the dominant Rvi6 allele (target fragment of 570 n.p) was not identified in the studied apple forms, which indicates their recessive homozygous genotype. The example of the SCAR electrophoretic spectrum of the AL07 marker is shown in Figure 1, the identification results are in the Table 1.

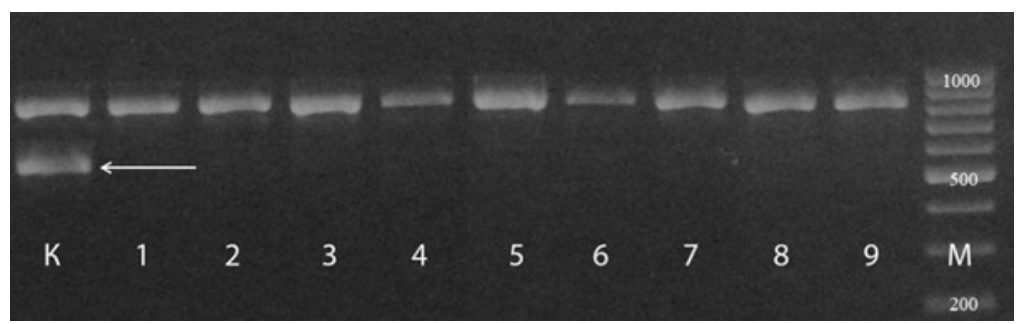

Fig. 1. Electrophoretic spectrum of SCAR marker AL07 of apple varieties of national selection.

K - Prima (control), 1 - Winter Antonovka, 2 - Terentyevka, 3 - Scarlet Anis, 4 - Suislepskoe, 5 Pouring yellow, 6 - Antonovka ordinary, 7 - Titovka, 8 - Cinnamon striped, 9 - Grushovka Moscowskaya, M - molecular weight marker 
Table 1. The allelic diversity of scab resistance genes in apple varieties of national selection ( 1 - allele present, 0 - no allele)

\begin{tabular}{|l|l|c|c|c|c|}
\hline \multirow{2}{*}{ № } & \multirow{2}{*}{ The apple varieties } & \multicolumn{2}{|c|}{ AL07-SCAR } & AD13-SCAR & OPL19-SCAR \\
\cline { 3 - 6 } & & Rvi6 & rvi6 & Rvi4 & Rvi2(Rvi8) \\
\hline 1 & Scarlet anise & 0 & 1 & 0 & 1 \\
\hline 2 & Pouring yellow & 0 & 1 & 0 & 1 \\
\hline 3 & Arkad red & 0 & 1 & 0 & 1 \\
\hline 4 & Suislepskoe & 0 & 1 & 0 & 1 \\
\hline 5 & Antonovka ordinary & 0 & 1 & 0 & 1 \\
\hline 6 & Antonovka red & 0 & 1 & 0 & 0 \\
\hline 7 & Antonovka kamenichka & 0 & 1 & 0 & 1 \\
\hline 8 & Winter Antonovka & 0 & 1 & 0 & 0 \\
\hline 9 & Mironchik & 0 & 1 & 0 & 1 \\
\hline 10 & Terentyevka & 0 & 1 & 0 & 0 \\
\hline 11 & Grushovka Moscowskaya & 0 & 1 & 1 & 1 \\
\hline 12 & Cinnamon striped & 0 & 1 & 0 & 1 \\
\hline 13 & Titovka & 0 & 1 & 1 & 1 \\
\hline
\end{tabular}

The target product of the AD13-SCAR marker is 950 p.n. (Rvi4 gene) in the analyzed collection of apple genotypes was found in the varieties Grushovka Moskovskaya and Titovka. The origin of these varieties is unknown, but the Rvi4 gene could presumably be introgressed from Malus sieversii, in the genome of some forms of which the Rvi4 gene was identified $[12,13]$. The rest of the studied apple genotypes have a recessive homozygous genotype (rvi4rvi4) (Figure 2, Table 1).

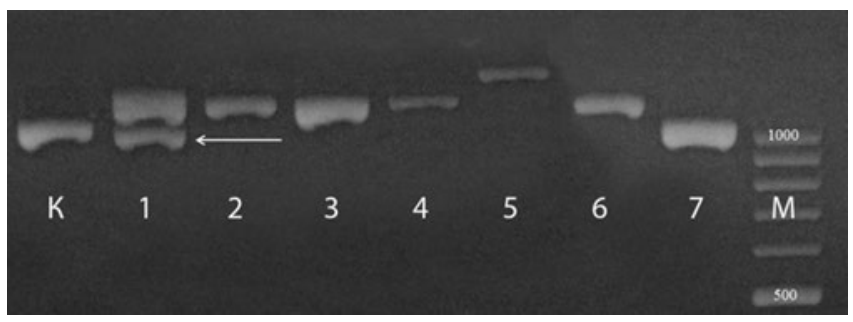

Fig. 2. Electrophoretic spectrum of SCAR marker AD13 of apple varieties of national selection

K - Kandil Orlovsky (control), 1 - Titovka, 2 - Anis scarlet, 3 - Suislepskoe, 4 - Pouring yellow, 5 - Terentyevka, 6 - Cinnamon striped, 7 - Grushovka Moscowskaya, M molecular weight marker

The SCAR marker OPL19 (433 p.n.) linked to the Rvi2 and Rvi8 genes was identified in 10 out of 13 cultivars (table). The resistance alleles of the Rvi2 and Rvi8 genes are absent in the varieties Antonovka Zimnyaya, Terentyevka, and Antonovka Krasnaya (genotype rvi2rvi2rvi8rvi8). An example of the electrophoretic profile of the OPL19-SCAR marker in apple varieties of national selection is shown in Figure 3. 


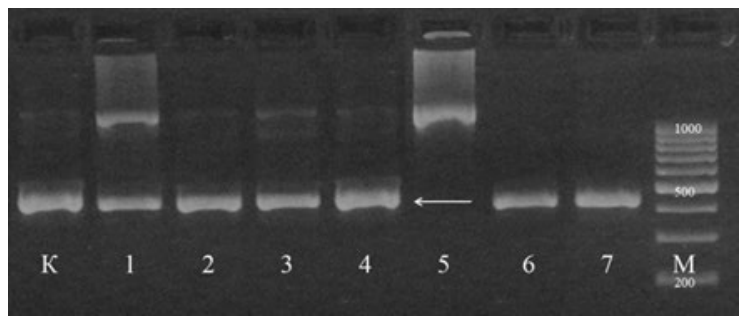

Fig. 3. Electrophoretic spectrum of the SCAR marker OPL19 of apple varieties of national selection

K - Witos (control), 1 - Titovka, 2 - Anis scarlet, 3 - Suislepskoe, 4 - Pouring yellow, 5 Terentyevka, 6 - Cinnamon striped, 7 - Grushovka Moscowskaya, M - molecular weight marker

The wide distribution of the OPL19-SCAR marker in the genoplasm of wild species and apple varieties, including local ancient varieties, is confirmed by our earlier studies [12, 14], as well as by the works of other scientists $[10,15]$.

The varieties such as Grushovka Moskovskaya and Titovka combine the markers AD13SCAR and OPL19-SCAR in the genotype, which indicates the presence of genes Rvi4 and Rvi2 (or Rvi8). In cultivars Terentyevka, Antonovka Krasnaya, and Antonovka Zimnyaya, markers of the studied resistance alleles were not revealed, which indicates a recessive homozygous state of all studied loci (rvi2rvi2rvi4rvi4rvi6rvi6rvi8rvi8).

Thus, as a result of the studies showed, the allelic state of the genes Rvi2, Rvi4, Rvi6, Rvi8 of resistance to scab in apple varieties of national selection was analyzed. The Rvi6 gene was not identified in the studied forms (putative rvi6rvi6 genotype). The Rvi4 gene was identified in the varieties Grushovka Moskovskaya and Titovka, which may have a dominant homozygous or heterozygous genotype. The Rvi2 or Rvi8 gene was identified in domestic varieties of folk selection Scarlet anis, Arkad red, Antonovka Kamenichka, Antonovka ordinary, Mironchik, Grushovka Moskovskaya, Titovka, Cinnamon striped, Pouring yellow, as well as the Baltic ancient variety Suislepskoe.

\section{References}

1. R. Cusin, L. F. Revers, F. D. S. Maraschin, Genet. Mol. Biol., 40(1), 305-311 (2017). https://doi.org/10.1590/1678-4685-gmb-2016-0043

2. M. A. Sheikh, K. M. Bhat, J. I. Mir, M. A. Mir, S. U. Nabi, M. A. Bhat, H. Ahmad, W. Shafi, S. Zaffer, S. Jan, W. H. Raja, Int. J, Chem. Stud., 5(4), 1107-1113 (2017). https://www.researchgate.net/publication/321528583_Phenotypic_and_molecular screening_for_disease_resistance of apple_cultivars and_selections_against appl e scab Venturia inaequalis

3. S. Kaymak, E. Kaçal, Y. Öztürk, IOBC-WPRS Bulletin, 91, 361-365 (2013). https://www.researchgate.net/publication/289536518_Screening_breeding_apple_p rogenies with vf apple scab Venturia inaequalis_ $\overline{C k e}$ Wint disease resistance gene specific molecular markers

4. D. Papp, J. Singh, D. Gadoury, A. Khan, Plant Dis., 104(3), 649-655 (2020). https://doi.org/10.1094/PDIS-10-19-2082-RE

5. G. Laloi, E. Vergne, C. E. Durel, B. Le Cam, V. Caffier, Plant Pathol., 66(3), 412422 (2017). 10.1111/ppa.12581 https://doi.org/10.1111/ppa.12581

6. L. Ebrahimi, K. B. Fotuhifar, M. Javan Nikkhah, M. R. Naghavi, N. Baisakh, PLoS One, 11(9), e0160737 (2016). https://doi.org/10.1371/journal.pone.0160737 
7. J. K. Bowen, C. H. Mesarich, V. G. Bus, R. M. Beresford, K. M. Plummer, M. D. Templeton, Mol. Plant Pathol., 12(2), 105-122 (2011). https://doi.org/10.1111/j.1364-3703.2010.00656.x

8. D. Papp, I. Király, M. Tóth, Org. Agr., 6(3), 183-189 (2016). https://doi.org/10.1007/s13165-015-0126-2

9. B. D. Lade, A. S. Patil, H. M. Paikrao, Springer Plus, 3(1), 457 (2014). https://doi.org/10.1186/2193-1801-3-457

10. R. Choupannejad, B. Sharifnabi, M. Bahar, M. Talebi, Sci. Hortic., 232, 107-111 (2018). https://doi.org/10.1016/j.scienta.2018.01.006

11. Y. P. Khajuria, S. Kaul, A. A. Wani, M. K. Dhar, Tree Gen. Genomes, 14(2), 16 (2018). https://doi.org/10.1007/s11295-018-1226-4

12. N. I. Savel'ev, A. S. Lyzhin, N. N. Savel'eva, Russ. Agricult. Sci., 42(5), 310-313 (2016). https://doi.org/10.3103/S1068367416050189

13. M. Tóth, I. Király, D. Papp, Kertgazdaság, 50(1), 16-29 (2018). https://www.researchgate.net/publication/324865490

14. A. S. Lyzhin, N. N. Savel'eva, Proceedings on Applied Botany, Genetics and Breeding, 181(1), 64-72 (2020). https://doi.org/10.30901/2227-8834-2020-1-64-72

15. J. Patzak, F. Paprštein, A. Henychová, Czech J. Genet. Plant Breed., 47(4), 156-165 (2011). https://www.agriculturejournals.cz/publicFiles/140_2011-CJGPB.pdf 